\title{
Strategi Branding Dan Pemasaran Produk Home Industry "Keripik Talas" Di Kelurahan Padangsambian, Denpasar
}

\author{
Ni Luh Putu Melyana Putri ${ }^{1}$, I G.N. Nyoman Wismantara ${ }^{2}$ \\ 1Jurusan Manajemen, Universitas Pendidikan Nasional \\ 2Jurusan Teknik Sipil, Universitas Pendidikan Nasional \\ Email: ${ }^{1}$ putumelyputri@gmail.com, 2 wismantara@undiknas.ac.id
}

\begin{abstract}
ABSTRAK
Kegiatan pengabdian masyarakat ini dilaksanakan di home industry "keripik talas" di Desa Padangsambian, Kecamatan Denpasar Barat, Kota Denpasar, Bali. Home Industry merupakan salah satu bentuk Usaha Mikro, Kecil, dan Menengah (UMKM). Dengan bertambahnya jumlah home industry setiap tahunnya tidak diikuti dengan kesadaran akan pentingnya branding dan kemampuan melakukan branding (pengemasan dan pelabelan) serta memasarkan produknya. Oleh karena itu, pelaksanaan kegiatan ini bertujuan untuk mengedukasi dan memberikan skill baru kepada pemilik home industry ini mengenai pentingnya branding (pengemasan dan pelabelan) serta pemasaran yang baik dan menarik untuk mencapai peningkatan penjualan. Metode yang digunakan adalah model penyuluhan dan pendampingan tentang pengemasan, pelabelan, dan pemasaran yang tepat dan menarik untuk produk "keripik talas". Hasil dari kegiatan pengabdian kepada masyarakat ini penyuluhan tentang pentingnya branding dan pemasaran. Selanjutnya dilakukan pendampingan pada branding (desain kemasan dan label) dan pemasaran dengan platform yang direkomendasikan agar produk menjadi lebih menarik, serta menambah nilai tambah dan penjualan produk
\end{abstract}

Kata Kunci: Keripik Talas, Pengemasan, Pelabelan, Pemasaran

This community service activity is carried out in the "taro chips" home industry in Padangsambian Village, West Denpasar District, Denpasar City, Bali. Home Industry is a form of Micro, Small, and Medium Enterprises (MSMEs). With the increase in the number of home industries each year, there is no awareness of the importance of branding and the ability to do branding (packaging and labeling) and market their products. Therefore, the implementation of this activity aims to educate and provide new skills to this home industry owner regarding the importance of branding (packaging and labeling) as well as good and attractive marketing to achieve increased sales. The method used is a model of counseling and mentoring on appropriate and attractive packaging, labeling, and marketing for "taro chips". The result of this community service activity is counseling on the importance of branding and marketing. Furthermore, assistance is carried out on branding (packaging and label design) and marketing with recommended platforms so that products become more attractive, as well as add added value and product sales.

Keywords: Taro Chips, Packaging, Labeling, Marketing 


\section{PENDAHULUAN}

Negara Indonesia merupakan sebuah negara agraris yang memiliki lahan pertanian hingga 107 juta hektar dari total luas daerah darat Indonesia yang mencapai 192 juta hektar (Hambali et al. cit. Rahman,2015; Setyawan \& Sari, 2016). Dengan luasnya lahan pertanian, beragam pangan yang berasal dari daerah di Indonesia dapat dijadikan alternatif dan perlu dikembangakan untuk mendukung ketahanan pangan diantaranya seperti kacang-kacangan, jagung, dan umbi-umbian seperti kentang, talas, dan ubi jalar. (Moorthy dan Pillai 1996; Silaban, Kardhinata, \& Hanafiah, 2019). Tanaman talas yang masuk ke dalam golongan umbi-umbian memiliki nama latin Colocasia esculenta (L.) Schott. Talas mudah untuk ditanam di Indonesia karena dapat tumbuh di daerah beriklim tropis dan tidak terlalu memerlukan pengairan. Selain itu, tanaman ini dapat hidup baik di dataran rendah maupun tinggi (Iskandar, Patang, \& Kadirman, 2018).

Olahan talas oleh masyarakat dibuat beragam seperti jajanan tradisional, kue bolu, hingga keripik. Dengan pengolahan yang yang masih sederhana memungkinkan untuk diolah oleh home industry (industri rumah tangga) sehingga dapat meningkatkan nilai jual talas. Salah satu contohnya yaitu Keripik Talas yang diproduksi oleh home industry di Kelurahan Padangsambian, kecamatan Denpasar Barat, kota Denpasar, Bali. Home industry ini merupakan salah satu wujud dari Usaha Mikro Kecil Menengah (UMKM). Di Indonesia, UMKM menjadi salah satu soko guru perekonomian koperasi. Bukti nyata yang dapat dilihat adalah UMKM khususnya home industry yang terhindar dari dampak krisis global pada tahun 2008 (Irrubai, 2015).

Home industry dari tahun ke tahun jumlahnya terus meningkat. Terlebih lagi, pada saat pandemi COVID-19, masyarakat mayoritas beralih membuka usaha kecilkecilan di rumah akibat pemutusan hubungan kerja (PHK) akibat dampak dari guncangan akibat pandemi COVID-19 yang menyebabkan gangguan di sebagian besar perusahaan saat ini. Namun, meningkatnya jumlah home industry belum sepenuhnya dibarengi dengan kesadaran pentingnya branding dan kemampuan untuk mem-branding (pengemasan dan pelabelan) dan memasarkan produk mereka. Saat mengamati usaha keripik talas di Kelurahan padangsambian, proses pengemasan produk mereka masih sederhana dan tidak adanya label pada kemasan produk. Begitu pula dengan cara pemasaran yang masih dari mulut ke mulut (word of mouth) dan menitipkannya di beberapa pedagang lain (reseller) sehingga perlu adanya penyuluhan dan pelatihan dalam rangka meningkatkan nilai tambah, profit, dan penjualan produk.

Dengan melihat hal tersebut, pengabdian masyarakat ini bertujuan untuk mengedukasi melalui penyuluhan dan melatih skill mereka dalam pendampingan yang dilakukan. Penyuluhan dan pendampingan ini mengenai bagaimana strategi branding (pengemasan dan pelabelan) dan pemasaran yang baik dan menarik sehingga dapat meningkatkan penjualan. Selain itu, penyuluhan tentang branding dan pemasaran sangat perlu untuk dilakukan karena penampilan merupakan aspek penting dari sebuah produk. Lima detik awal pandangan konsumen merupakan hal yang sangat menentukan keputusan konsumen untuk memilih sebuah produk (Irrubai, 2015).

Dilihat dari kondisi di lapangan, Pemilik Home Industry "Keripik Talas" belum menyadari pentingnya kemasan, label, dan pemasaran yang baik dan menari. Sehingga solusi yang dapat dilakukan mengenai hambatan yang dialami home industry di wilayah Kelurahan Padangsambian, Kecamatan Denpasar Barat, Kota Denpasar yaitu, (1) membangun kesadaran pemilik home industry melalui penyuluhan mengenai pentingnya pengemasan, pelabelan, dan pemasaran produk yang baik dan menarik; (2) memberikan pendampingan kepada pemilik home industry mengenai cara pembuatan kemasan, label, dan pemasaran yang baik dan menarik; dan (3) memberikan rekomendasi relasi yang dapat memfasilitasi pembuatan 
kemasan, label, dan pemasaran yang baik dan menarik.

Adapun strategi yang bisa diterapkan untuk pengemasan, pelabelan, dan pemasaran yaitu menggunakan bauran pemasaran (marketing mix) dengan item yang dapat digunakan yaitu Product, Price, Place, dan Promotion (Irrubai, 2015). Dari segi product, pemilik usaha keripik talas dapat membuat label yang diletakkan pada kemasan produk. Kemasan yang bisa digunakan adalah standing pouch ziplock yang transparan agar produk dapat dilihat dan terlindungi dengan baik. Untuk harga (price), akan disesuaikan terhadap perbedaan berat produk. Selanjutnya, untuk tempat penjualan produk (place), keripik talas dapat dijual di online market place dan tetap menggunakan reseller. Berhubung dengan tempat pemasaran produk, promosi (promotion) dapat dilakukan dengan membuat konten kreatif di beberapa platform media sosial seperti Instagram.

Dengan adanya kuliah kerja nyata yang dilakukan di Kelurahan Padangsambian diharapkan dapat memberikan manfaat kepada Kelurahan Padangsambian dalam memaksimalkan potensi dan menyelesaikan masalah yang dimiliki dan dapat terbantu dalam mengembangkan dan meningkatkan ekonomi masyarakat dan kualitas industri rumah tangga di wilayah tersebut. Selain itu, pada pemilik home industry juga diharapkan dapat terbantu dalam pengembangan usaha mereka dan dapat terbantu dalam mengetahui bagaimana strategi yang tepat untuk branding (pengemasan dan pelabelan) dan pemasaran untuk produk mereka agar nilai jual meningkat dan tetap dilirik konsumen. Hasil akhir yang diinginkan dalam pengabdian ini yaitu terciptanya desain kemasan dan label serta cara pemasaran yang baik dan efektif sehingga meningkatkan nilai tambah produk dan penjualan produk keripik talas.

\section{METODE PELAKSANAAN}

Metode pelaksanaan yang diterapkan dalam kegiatan pengabdian masyarakat ini menggunakan metode penyuluhan dan pendampingan. Adapun rincian pelaksanaan kegiatan kuliah kerja nyata ini yaitu, (1) kegiatan pertama yaitu peninjauan lapangan yang dilakukan oleh pengabdi sebelum penyuluhan dan pengabdian untuk mengetahui kondisi lapangan; (2) Selanjutnya, kegiatan penyuluhan ini dilaksanakan. Adapun materi penyuluhan ini yaitu edukasi mengenai pentingnya kemasan dan label agar dapat menciptakan nilai tambah untuk produk. Selain itu, penyuluhan ini juga mengedukasi pemilik home industry mengenai cara pemasaran yang baik dan menarik; (3) Setelah penyuluhan terlaksana maka selanjutnya dilakukan metode pendampingan. Peserta didampingi oleh pengabdi terkait proses pembuatan desain kemasan dan label, pembuatan platform dan konten pemasaran, pendampingan dalam proses promosi keripik talas, serta pendampingan dalam menciptakan rencana pemasaran yang baik dan menarik agar meningkatkan nilai jual dan tetap dilirik oleh konsumen.

Kegiatan ini, melibatkan pemilik usaha yang juga mengkoordinir pekerjanya dengan total 5 orang dengan 1 orang pengabdi. Setelah penyuluhan dan pendampingan selesai dilaksanakan, target yang diharapkan yaitu, pemilik home industry diharapkan mengerti mampu menciptakan kemasan dan label yang baik dan menarik. Pemilik home industry juga diharapkan untuk mengerti dan mampu menerapkan cara pemasaran yang baik dan menarik secara berkelanjutan agar dapat menarik minat konsumen untuk membeli produk sehingga penjualan dapat meningkat.

Teknik pengumpulan data yang dilakukan yaitu, dengan cara terjun langsung dalam proses produksi keripik talas. Kemudian dari data lapangan yang ditemukan selanjutnya dianalisis dan dibentuk sebuah solusi berdasarkan bauran pemasaran (marketing mix) dengan item Product, Price, Place, dan Promotion. Kemudian, setelah realisasi kegiatan selesai, survei juga dilakukan dengan maksud untuk mengetes pasar secara sederhana di masyarakat sekitar untuk mengetahui tanggapan konsumen mengenai 
branding (pengemasan dan pelabelan) yang telah dibuat. Kegiatan ini dilakukan selama 45 hari, yaitu dari 1 Februari hingga 17 Maret 2021.

Tabel 1. Indikator Keberhasilan Program

\begin{tabular}{|c|c|c|}
\hline \multirow[t]{2}{*}{ Kriteria } & \multicolumn{2}{|c|}{ Analisis } \\
\hline & Sebelum & Sesudah \\
\hline Pengetahuan & $\begin{array}{l}\text { Produsen } \\
\text { belum } \\
\text { mengetahui } \\
\text { Branding dan } \\
\text { cara } \\
\text { pemasaran } \\
\text { memiliki } \\
\text { pengaruh } \\
\text { terhadap } \\
\text { niat beli dan } \\
\text { penjualan. }\end{array}$ & $\begin{array}{l}\text { Produsen } \\
\text { sudah } \\
\text { mengetahui } \\
\text { Branding } \\
\text { dan cara } \\
\text { pemasaran } \\
\text { memiliki } \\
\text { pengaruh } \\
\text { terhadap } \\
\text { niat beli } \\
\text { dan } \\
\text { penjualan. }\end{array}$ \\
\hline $\begin{array}{l}\text { Sikap } \\
\text { dan } \\
\text { Kesadaran }\end{array}$ & $\begin{array}{l}\text { Branding dan } \\
\text { pemasaran } \\
\text { belum } \\
\text { dianggap } \\
\text { penting oleh } \\
\text { produsen. }\end{array}$ & $\begin{array}{l}\text { Branding } \\
\text { dan } \\
\text { pemasaran } \\
\text { Sudah } \\
\text { dianggap } \\
\text { penting } \\
\text { oleh } \\
\text { produsen. }\end{array}$ \\
\hline Keterampilan & $\begin{array}{l}\text { Produsen } \\
\text { belum bisa } \\
\text { membuat } \\
\text { kemasan } \\
\text { label, akun } \\
\text { Instagram, } \\
\text { serta konten } \\
\text { pemasaran } \\
\text { produk yang } \\
\text { menarik }\end{array}$ & $\begin{array}{l}\text { Produsen } \\
\text { belum bisa } \\
\text { membuat } \\
\text { kemasan } \\
\text { label, akun } \\
\text { Instagram, } \\
\text { serta konten } \\
\text { pemasaran } \\
\text { produk } \\
\text { yang } \\
\text { menarik }\end{array}$ \\
\hline
\end{tabular}

\section{HASIL DAN PEMBAHASAN}

Home industri "keripik talas" yang ada di Kelurahan Padangsambian, Denpasar Barat, Bali selama berjalan masih mengalami kendala terkait pemasaran kurang maksimal. Hal ini dikarenakan branding (pengemasan dan pelabelan) yang belum dibuat dengan baik sehingga pengembangan usaha ini menjadi terhambat. Oleh sebab itu, pengabdian ini dilakukan untuk memberikan penyuluhan dan pendampingan untuk memecahkan masalah yang berkaitan dengan strategi pemasaran yang belum dilaksanakan secara maksimal akibat tidak adanya pengemasan dan pelabelan yang dilakukan. Kegiatan penyuluhan dan pendampingan ini dilakukan secara online akibat situasi Pandemi COVID19

Adapun proses pembuatan keripik talas ini masih tergolong sederhana. Hal ini karena, dalam proses pengolahan dari talas hingga menjadi keripik, produksinya sama sekali belum menggunakan teknologi. Pada awal pembuatan, bahan baku talas akan dikupas terlebih dahulu hingga bersih. Kemudian, talas yang telah dikupas akan dicuci dengan bersih menggunakan air hingga tidak ada kotoran yang tersisa. Jika sudah bersih, talas akan diparut menggunakan parutan khusus agar berbentuk persegi panjang dan tipis hingga bisa bentuk. Sesudah selesai proses pemarutan, talas akan dicampur dengan bumbu-bumbu seperti cabai, bawang merah, bawang putih, penyedap rasa, garam, daun jeruk, dan tepung tapioka. Jika sudah tercampur rata, adonan siap dibentuk dan di goreng. Apabila sudah dingin maka siap untuk dikemas.

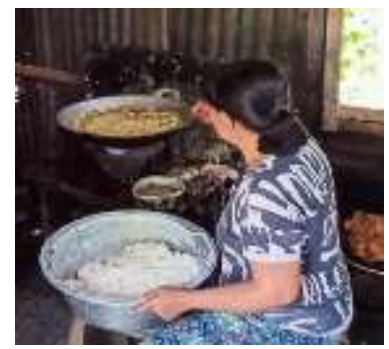

Gambar 1. Pengolahan talas menjadi keripik talas

Kemudian, pelaksanaan kegiatan penyuluhan dilakukan pertama kali setelah melakukan peninjauan lapangan. Pada kegiatan penyuluhan ini, pelaku home industry "keripik talas" di Kelurahan Padangsambian diberitahu bagaimana pentingnya penggunaan kemasan dan label. Dengan adanya label, produk usaha ini akan mudah untuk dikenali oleh konsumen. Sedangkan, 
pembuatan kemasan yang menarik diharapkan dapat meningkatkan nilai tambah produk dan minat beli konsumen terhadap produk keripik talas.

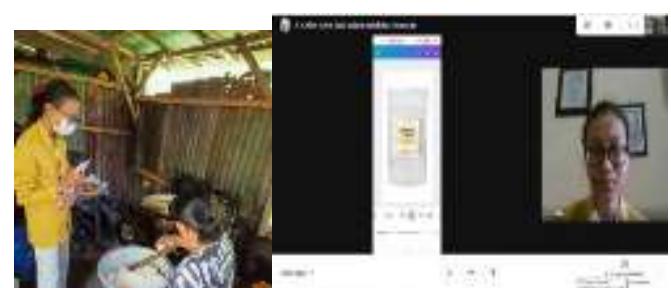

Gambar 2. Penyuluhan dan pendampingan Home Industry "Keripik Talas" Kelurahan

Padangsambian

Selain penyuluhan, pengabdian ini dilanjutkan dengan pendampingan pembuatan label dan kemasan. Proses pembuatan kemudian dilakukan bersama dengan produsen mengenai desain yang disukai dan disetujui untuk digunakan. Label yang dibuat telah berisikan nama produk, alamat produksi, alamat pemesanan, dan komposisi produk. Disamping itu, untuk kemasan yang digunakan yaitu berisi ziplock agar daya tahan produk lama dan kualitas tetap baik hingga ke tangan konsumen.
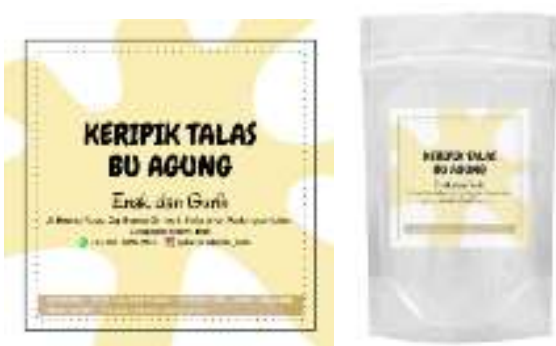

Gambar 3. Desain Label dan Kemasan yang disetujui produsen

Pendampingan selanjutnya yaitu pada pembuatan akun dan konten pada platform media sosial seperti instagram. Pembuatan akun dan konten ini diharapkan dapat menjangkau lebih banyak orang, memperluas pasar, meningkatkan kesadaran masyarakat akan produk ini, memudahkan konsumen memesan, dan memudahkan konsumen mendapatkan info mengenai produk keripik talas ini. Adapun pada instagram, informasi yang dicantumkan yaitu cara pemesanan, daftar harga, ketersediaan stock, dan tampilan produk.

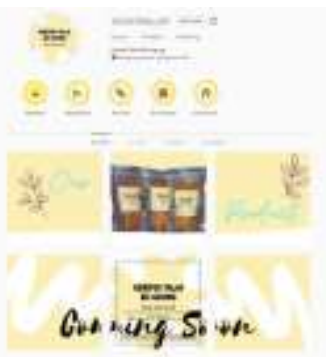

Gambar 4. Tampilan akun Instagram Home Industry "Keripik Talas" Kelurahan Padangsambian

Pada tahapan akhir, survei dilakukan untuk mengetahui tanggapan konsumen mengenai branding (pengemasan dan pelabelan) yang telah dibuat. Dengan hal ini, proses pemasaran melalui media sosial dapat optimal dan sesuai dengan selera pasar. Dari hasil survei sederhana yang dilakukan, konsumen lebih tertarik terhadap kemasan yang baru. Dengan demikian, dapat dikatakan kemasan baru ini mendapat respon positif di masyarakat. Oleh sebab itu, desain kemasan ini akan diterapkan seterusnya oleh produsen agar meningkatkan nilai tambah produk, profit dan mencapai penjualan produk yang maksimal.

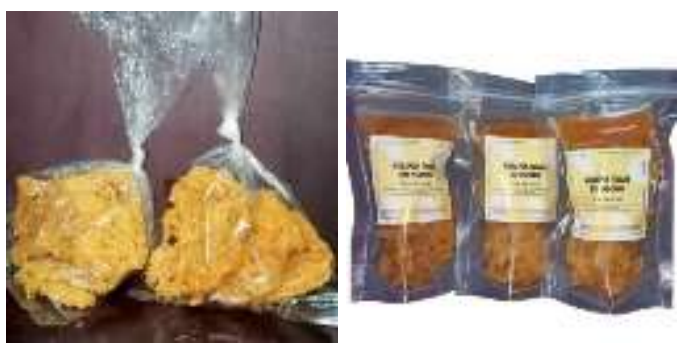

Gambar 5. Hasil Kemasan produk sebelum dan sesudah

\section{SIMPULAN DAN SARAN}

\section{Simpulan}

Melalui kegiatan pengabdian masyarakat yang telah terlaksana, maka simpulan yang dapat diambil yaitu sebagai berikut:

1) Kegiatan yang dilakukan pada Home Industry "Keripik Talas" di Kelurahan Padangsambian, Kecamatan Denpasar Barat, Kota Denpasar Bali tentang pendampingan pembuatan kemasan, 
label, dan cara pemasaran yang baik dan menarik pada produk home industry terlaksana dengan baik dan lancar. Serta, peserta mengikuti kegiatan dengan antusias.

2) Melalui metode yang diterapkan diharapkan dapat meningkatkan kesadaran para pelaku home industry bahwa kemasan, label, dan cara pemasaran memiliki peran penting dalam menarik minat beli konsumen. Dengan kemasan yang menarik juga berpotensi dalam memberikan nilai tambah pada produk (value added) keripik talas.

\section{Saran}

Saran yang dapat diberikan kepada pemilik home industry dan pengabdi masyarakat selanjutnya setelah kegiatan ini berakhir yaitu,

1. Pemilik disarankan membuat diferensiasi produk agar lebih bervariasi dan menawarkan pilihan kepada konsumen. Sehingga, untuk pengabdian selanjutnya dapat mengembangkan variasi produk.

2. Pemilik dapat mengoptimalkan penggunaan platform media sosial seperti Instagram. Maka, untuk pengabdian selanjutnya dapat membuat program pembelajaran seperti cara meningkatkan awareness pengguna instagram

3. Pemilik dapat mengembangkannya penggunaan platform-platform lain seperti Facebook ataupun Tiktok sebagai media pemasaran produk sehingga dapat meningkatkan awareness masyarakat terhadap produk ini. Maka, pengabdian selanjutnya dapat membuat program mengenai hal ini.

4. Pemilik harus mendaftarkan produk home industry "keripik talas" ke Dinas Kesehatan dan Dinas Perindustrian, Perdagangan, dan Koperasi untuk mendapatkan nomor register industri rumah tangga. Hal ini berguna dalam memudahkan usaha ini untuk meluaskan uasahanya. Sehingga hal itu dapat berimbas pada peningkatan produksi yang diharapkan akan dapat menciptakan lapangan kerja baru bagi warga dan menyerap tenaga kerja baru. Maka, untuk pengabdian selanjutnya dapat membantu pemilik home industry untuk mendaftarkan produknya

5. Kelurahan Padangsambian diharapkan dapat menciptakan kurikulum desa untuk memberikan ilmu dan wawasan baru kepada pemilik home industry di wilayahnya agar dapat berkembang dan menjadi Kelurahan yang masyarakatnya maju, mandiri, dan sejahtera.

\section{DAFTAR PUSTAKA}

Irrubai, M. L. (2015). Strategi Labeling, Packaging dan Marketing Produk Hasil Industri Rumah Tangga di Kelurahan Monjok Kecamatan Selaparang Kota Mataram Nusa Tenggara Barat. Jurnal Jurusan Pendidikan IPS Ekonomi.

Iskandar, H., Patang, \& Kadirman. (2018). Pengolahan Talas (Colocasia Esculenta L., Schott) Menjadi Keripik Menggunakan Alat Vacum Frying Dengan Variasi Waktu. Jurnal Pendidikan Teknologi Pertanian, 29-42.

Moorthy \& Pillai. 1996. Physicochemical properties of starch some accessions of Taro. In Kurup et al.

Rahman, Syamsul. 2015. "Analisis Nilai Tambah Agroindustri Chips Jagung" dalam Jurnal Aplikasi Teknologi Pangan 4.

Setyawan, F., \& Sari, P. N. (2016). Labelling Kemasan Sebagai Upaya Pengembangan Pemasaran Agroindustri Emping Jagung di Desa Tirtomulyo, Kretek, Bantul. Indonesian Journal of Community Engagement.

Silaban, E. A., Kardhinata, E. H., \& Hanafiah, D. S. (2019). Inventarisasi dan Identifikasi Jenis Tanaman Talas-Talasan dari Genus Colocasia dan Xanthosoma di Kabupaten Deli Serdang dan Serdang Bedagai. Jurnal Agroekoteknologi FP USU, 46-54. 